\title{
Ten years of recovery after experimental fire in a heathland: effects of sowing native species
}

\author{
Isabel Fernández-Abascal, Reyes Tárrega*, \\ Estanislao Luis-Calabuig \\ Area de Ecología, Facultad de Ciencias Biológicas y Ambientales, Universidad de León, 24071 León, Spain
}

Received 9 September 2003; received in revised form 25 May 2004; accepted 21 July 2004

\begin{abstract}
The effect of revegetation with different combinations of native species in the recovery dynamic of a shrubland dominated by Erica australis subjected to experimental fire was studied. The herbs sown had very low cover throughout the study period. Amongst the species of shrubs, Cytisus spp. develops cover above 50\% from the fourth year after sowing in the plots where it was sown and colonisation is observed in the unsown ones from the ninth year. Quercus pyrenaica seedlings have a survival rate of $50 \%$, but their mean height does not reach $40 \mathrm{~cm}$ after nine years. The shrub and herbaceous species present in the area before experimental burning are characterised by their great resilience, resprouting vegetatively or recovering from seed. It is therefore not possible to detect significant differences among the plots subjected to the different revegetation treatments and the controls regarding woody, herbaceous or total cover, nor are any significant differences observed in the diversity counted as number of species (richness). The good development of Cytisus spp. points to an important physiognomic change and this, together with the high survival rate, although not growth so far, of $Q$. pyrenaica may influence the long-term dynamic of the community.

(C) 2004 Published by Elsevier B.V.
\end{abstract}

Keywords: Experimental burning; Revegetation; Erica australis shrubland; Succession

\section{Introduction}

Fire has been considered a key factor in maintaining the structure and functioning of the Mediterranean ecosystems (Naveh, 1974) and has been used as a traditional management tool by farmers and shepherds. Traditional shepherd fires burned in small

\footnotetext{
* Corresponding author. Tel.: +34 987 291567; fax: +34987291501.

E-mail address: degelc@unileon.es (R. Tárrega).
}

patches and were of low intensity, with most of plant biomass being herbaceous species because livestock limited shrub expansion. However, the socio-economic changes of the last decades caused the people migration from rural areas to the cities and consequently the massive abandonment of pastures and crops. This has brought an enormous spread in heathland communities (Luis-Calabuig et al., 2000; Pérez et al., 2003), covering 33\% of the surface in León province (NW Spain). The shrubland expansion has been associated with a considerable increase in the 
number of fires and burned areas in the European Mediterranean (Moreno et al., 1998; Pausas and Vallejo, 1999) because of greater spatial continuity of fuel biomass, with flammability and combustibility increasing as water contents diminish with stand age (Fernández-Abascal et al., 2002). Forest fires are presently one of the most serious threats to ecosystem conservation not only because of vegetation destruction but also because of the soil loss, which seriously jeopardises possible recovery (Vallejo and Alloza, 1998). The species of most Mediterranean shrublands, like Erica australis heathlands, can resprout vegetatively after a fire, so recovery is by autosuccession and quite fast (Naveh, 1974; Trabaud, 1987; Reyes et al., 2000; Calvo et al., 2002). The main risk of erosion loss is therefore only in the first stages (Diaz-Fierros et al., 1990; Marcos et al., 2000).

One of the most commonly used methods of reducing erosion losses is to sow herbaceous species to protect the soil, especially during the first year (Ruby, 1989). Lolium multiflorum or a mixture of grasses and legumes have been widely used; the effectiveness of this treatment is low to moderate, according to the environmental conditions of the burned and then sown areas, and is particularly dependent on post-sowing meteorological conditions (Miles et al., 1989; Fernández-Abascal et al., 1998, 2003). Those who disparage this technique state that sown vegetation interferes with natural recolonization and may have long-term effects on post-fire vegetation composition and structure (Conard et al., 1995). However, other authors (Vallejo and Alloza, 1998; Alberdi and Cavero, 2001) showed that sowing herbaceous species caused an initial increase in cover, which does not interfere with natural recovery.

On the other hand, most shrub communities in the Mediterranean basin are highly persistent secondary stages with no apparent successional advance towards mature forest stages. In some cases, this is due to the degree of soil degradation but in others it is due to the difficulty tree seeds have to reach and become established in these zones (Luis-Calabuig et al., 2000; Vallejo et al., 2000; Reyes and Casal, 2002; Espelta et al., 2003). Therefore, tree species need to be introduced if accelerated forest recovery is required. The advantage of introducing shrub species resilient to fire in order to favour natural regeneration in the case of another fire occurring has also been pointed out
(Vallejo and Alloza, 1998; Vallejo et al., 2000). In this sense, Cytisus spp. has a great capacity to recover both from seed and by resprouting (Tárrega et al., 1992; Fernández-Santos and Gómez-Gutierrez, 1994; Fernández-Santos et al., 1999; Pérez et al., 2003) and has the added advantage of possessing atmospheric nitrogen symbiont fixers, which could favour the growth of other species, although also competing against them (Watt et al, 2003).

This paper is part of a wider study in which different combinations of herbaceous and woody species were tested for the revegetation of experimentally burned heathland. Our aim was to find the most suitable combination of species to slow erosion on a short-term basis and favour succession towards forest in the long term. In previous studies, the effects on soil have been analysed (Marcos et al., 2000), as well as plant recovery in the first phases after burning and sowing (Fernández-Abascal et al., 1998). In these studies, it can be observed that the sown herbaceous species were not very abundant. This paper tries to determine whether in the long term (10 years after burning and nine after sowing) the herbs sown have any influence on regeneration of the plant community. On the other hand, amongst the woody species sown, Cytisus spp. became well established. Quercus pyrenaica also had a good survival rate, although not a good growth one. Marcos et al. (2004) discusses the possible interaction between Cytisus spp. and the dominant species in the area (E. australis). Here we intend to show its possible effect on the community dynamic. Therefore, the aim of this paper is to determine the effects of the different species used for revegetation on the post-fire recovery of the heathland over a period of 10 years. The changes in species diversity and cover in terms of the type of sowing are therefore compared.

\section{Materials and methods}

The study was conducted in an E. australis subspecies aragonensis heathland in the province of León (NW Spain), M.T.U. coordinates: 30TUN282277. The slope is $10 \%$, orientation N-NE and elevation $1063 \mathrm{~m}$ above sea level. The climate is subhumid Mediterranean, with a dry period in summer, although the spring in 1994 and 1995 was 
abnormally dry. Late succession vegetation should be $Q$. pyrenaica forest, but most of the area is heathland, as a result of pasture being abandoned in the 1960s with human migration from rural areas. The mean aboveground biomass was about $1700 \mathrm{~g} / \mathrm{m}^{2}$, with most of this biomass $\left(1000 \mathrm{~g} / \mathrm{m}^{2}\right)$ contributed by E. australis (Fernández-Abascal et al., 2002), with a mean cover of $50 \%$ and a mean maximum height of $1 \mathrm{~m}$. Other abundant shrubs are Calluna vulgaris (mean cover $25 \%$, mean biomass $600 \mathrm{~g} / \mathrm{m}^{2}$ ) and Arctostaphylos uva-ursi (mean cover 60\%, mean biomass $200 \mathrm{~g} / \mathrm{m}^{2}$ ), with Chamaespartium tridentatun, Halimium alyssoides and H. umbellatum also appearing.

Three $18 \mathrm{~m} \times 10 \mathrm{~m}$ plots were burned in July 1993 . During the experimental fire, the Forestry Service (Centro de Investigaciones Forestales de Lourizán, Ministry of the Environment) measured environmental data (relative humidity $=38.8 \%$, ambient temperature $=33{ }^{\circ} \mathrm{C}$ ) and confirmed that fire behaviour (flame height $=10 \mathrm{~m}$, rate of spread $=2 \mathrm{~m} \mathrm{~min}^{-1}$, maximum average temperature at litter $=563{ }^{\circ} \mathrm{C}$ ) was similar to typical fires in these communities (Marcos et al., 2000). The plots were revegetated in March 1994 using different species combinations, all of them natural to the area. The area was surrounded by a $2 \mathrm{~m}$ high fence to prevent livestock (sheep) from entering. Two of the revegetated plots were used for the study of edaphic and erosion changes (Marcos, et al., 2000) and the third for the detailed vegetation study. This paper gives the results obtained in the third plot. Fifteen permanent $4 \mathrm{~m}^{2}$ small plots were established in each plot (four treatments and a control replicated three times), according to the scheme in Fig. 1.

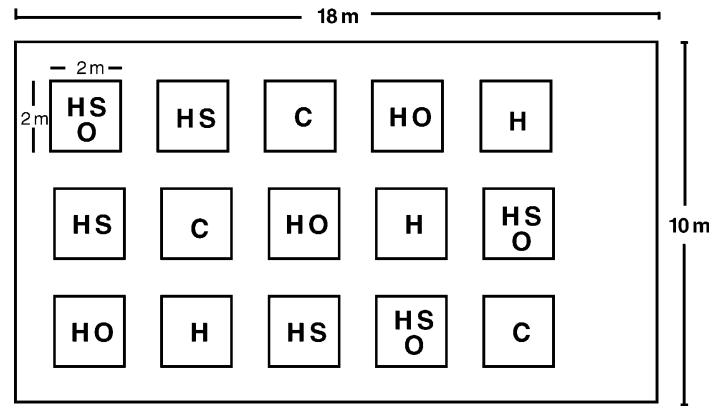

Fig. 1. Distribution of the $4 \mathrm{~m}^{2}$ small plots in the study plot. $(\mathrm{C}=$ control, $\mathrm{H}=$ herbaceous species, $\mathrm{S}=$ shrub species, $\mathrm{O}=$ oak seedlings).
The treatments were randomly assigned to plots, but without repetition in the same row or column. Seed quantity was estimated by weight in order to have 20,000 seeds, equally divided amongst the species assigned to each treatment, per square meter in each plot sown.

a) Sowing of herbs (H plots): Lotus corniculatus (40 g), Agrostis capillaris (2.4 g) and Festuca rubra $(34 \mathrm{~g})$.

b) Sowing of herbs and shrubs (HS plots): $L$. corniculatus $(20 \mathrm{~g})$, A. capillaris $(1.2 \mathrm{~g})$, F. rubra (16 g), Cytisus spp. (10 g), C. vulgaris (7 g) and E. australis $(24 \mathrm{~g})$.

c) Sowing of herbs and plantation of oaks (HO plots): L. corniculatus $(20 \mathrm{~g})$, A. capillaris $(1.2 \mathrm{~g})$, F. rubra (16 g) and $Q$. pyrenaica (4 oak seedlings, two months old).

d) Sowing of herbs and shrubs and plantation of oaks (HSO plots): L. corniculatus (20 g), A. capillaris (1.2 g), F. rubra (16 g), Cytisus spp. (10 g), C. vulgaris $(7 \mathrm{~g})$, E. australis $(24 \mathrm{~g})$ and $Q$. pyrenaica (4 oak seedlings, two months old).

e) Unsown control plots with natural post-fire regeneration (C plots).

The oak and shrub seeds were purchased from the Forest Nursery, Nature Conservation Institute (ICONA); the shrub seeds were subjected to heat treatment at $100{ }^{\circ} \mathrm{C}$ for $10 \mathrm{~min}$ before sowing to stimulate germination (Tárrega at al., 1992). In the case of Cytisus, a combination of Cytisus scoparius and $C$. striatus was used. Both species coexist in these areas, though they were not found in plot sampling conducted before the experimental fire. The herbs were commercial varieties with a high germination index and thus were not subjected to any pretreatment. Species germination capacity was analyzed in the laboratory by placing 100 seeds of each species in Petri dishes on filter paper soaked in distilled water. In the case of shrub and herb species, sowing was by scattering the seed. Oak seedlings were obtained from germination of seeds in the laboratory.

In order to know the plant composition in the initial situation, a sampling was carried out in June 1993 before the experimental fire. Twelve $1 \mathrm{~m}^{2}$ quadrats, randomly situated in the $16 \mathrm{~m} \times 10 \mathrm{~m}$ plot, were sampled. After sowing, samplings were carried out in 
June 1994-1999 and 2003. Cover percentage of all the plant species present was visually estimated. A $0.25 \mathrm{~m}^{2}$ quadrat was used, analyzing four units in each $4 \mathrm{~m}^{2}$ plot and each sampling period. The mean of the four quadrats from each plot was considered for subsequent analysis ( $1 \mathrm{~m}^{2}$ sampling unit). The nomenclature of the species follows Flora Europaea (Tutin et al., 19641980). The number of $Q$. pyrenaica seedlings (live above ground biomass) was counted in all the samplings and their height was measured in 1995 and 2003.

The results of total cover, herb and woody cover, and cover of each species sown in each treatment (after arc-sine transformation) as well as species richness were compared using analysis of variance. When the changes over time in the same plot were considered, a repeated measures analysis of variance was used. The Scheffe-test (Scheffe, 1959) was applied for a comparison between pairs when ANOVA was significant $(p$ $<0.05)$. Sample normality was checked beforehand using the David test (David et al., 1954) and the homogeneity of variances with the Cochran test (Cochran, 1941).

A correspondence analysis was used in order to compare the plant composition (CANOCO Program, Ter Braak, 1991). In this case, the mean values of the replicates (three similar plots in each sampling period, and the mean of the twelve $1 \mathrm{~m}^{2}$ quadrats in the case of initial situation) were considered. Species, which appeared only twice, were not taken into account. So 40 species and 36 samplings were included in the analysis.

\section{Results}

Good results were observed for the herbs, above all F. rubra and for Cytisus spp. in the tests carried out in

Table 1

Results of germination in the laboratory for the seeds of sown species

\begin{tabular}{ll}
\hline Species & Germination \\
\hline Erica australis & $0 \%$ \\
Calluna vulgaris & $0 \%$ \\
Cytisus spp. & $51 \%$ \\
Agrostis capillaris & $40 \%$ \\
Festuca rubra & $94 \%$ \\
Lotus corniculatus & $75 \%$ \\
\hline
\end{tabular}

the laboratory to determine the germination rates of the species used for revegetation (Table 1). However, neither E. australis nor C. vulgaris germinated.

There are, generally, no significant differences in the cover of the three herbs sown among treatments. $F$. rubra and A. capillaris usually present higher mean cover in the sown plots than in the controls, whereas $L$. corniculatus is significantly more abundant in the sown plots $(p=0.008)$ only in the first sampling, and its cover is very low in all cases (Fig. 2). Considering the cover of the three species as a whole, significant differences were only recorded between the control plots and the rest in the 1996 sampling.

As regards the shrub species, $C$. vulgaris does not begin to appear until 1999 (Fig. 3) and probably comes from the soil seed bank, since it was abundant in the area before burning and the laboratory germination rate for the seeds sown was zero; no differences are observed between the different treatments, although they are in comparison with the initial situation. E. australis is abundant from the first samplings in all the plots but comes from vegetative resprout, which allows it to recover more rapidly. Cytisus spp. appears in the sown plots after one year (J.95), but no significant differences can be detected until the following year, and this is maintained throughout the study period $(p<0.004)$; however, there are no differences between the HS and HSO plots. Colonization of the unsown plots by Cytisus spp. can be clearly seen in the last sampling.

The $Q$. pyrenaica seedlings have a survival rate of $50 \%$, which remains practically constant from the first sampling (Table 2). The apparent increase from J.94 to J.95 as well as the other oscillations in the number of

Table 2

Number of Quercus pyrenaica seedlings in each plot $(\mathrm{HO}=$ herbs + oaks, $\mathrm{HSO}=$ herbs + shrubs + oaks $)$ and mean cover in each sampling period $(\mathrm{J} .94=$ June 1994, J.03 = June 2003)

\begin{tabular}{llllllll}
\hline PLOT & J.94 & J.95 & J.96 & J.97 & J.98 & J.99 & J.03 \\
\hline HO1 (Number) & 2 & 1 & 1 & 1 & 1 & 1 & 1 \\
HO2 (Number) & 1 & 3 & 3 & 3 & 3 & 3 & 3 \\
HO3 (Number) & 0 & 1 & 1 & 1 & 1 & 1 & 1 \\
HSO1 (Number) & 4 & 4 & 1 & 2 & 4 & 4 & 4 \\
HSO2 (Number) & 0 & 1 & 1 & 1 & 1 & 1 & 1 \\
HSO3 (Number) & 1 & 2 & 2 & 2 & 2 & 2 & 2 \\
HO Mean cover & 0.08 & 0.01 & 0.08 & 1.42 & 1.25 & 1.67 & 3.33 \\
HSO Mean Cover & 0.17 & 0.50 & 0.75 & 2.67 & 2.08 & 2.50 & 11.67 \\
\hline
\end{tabular}



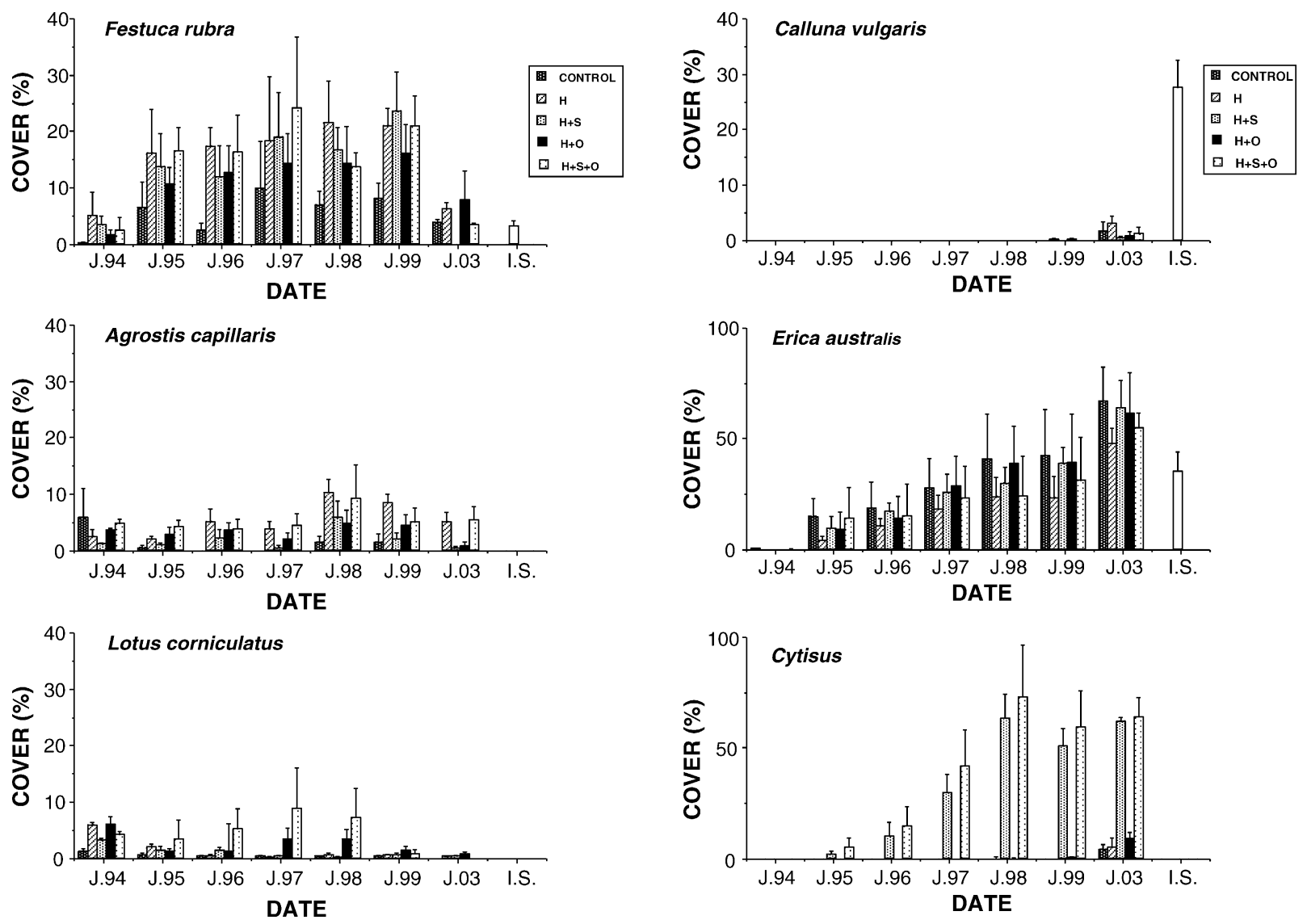

Fig. 2. Mean and standard error of cover values of Festuca rubra, Agrostis capillaris and Lotus corniculatus in the plots during the study period.

seedlings are due to the mortality of the aboveground biomass of some seedlings at some sampling period, but survival of the roots allows them to recover and reappear in later samplings. In the last five years (from J.98), these changes are not observed. In spite of the good survival response, growth is very limited with mean cover below $3 \%$ until the last sampling and with statistically significant differences between sampling $\mathrm{J} .03$ and the previous ones $(p=0.001)$. Mean cover is always greater in the HSO than the HO plots and the difference tends to increase in the last sampling, although statistically significant differences $(p=0.19)$ cannot be detected. The mean height of the seedlings was $11 \mathrm{~cm}$ one year after planting (J.95). After nine years (J.03), it had increased significantly ( $p=$ $0.0004)$, but by a small amount, only $23 \mathrm{~cm}$ in the

Fig. 3. Mean and standard error of cover values of Calluna vulgaris, Erica australis and Cytisus spp. in the plots during the study period.

$\mathrm{HO}$ plots and $35 \mathrm{~cm}$ in the HSO ones. Moreover, the differences in height in these two types of plot were statistically significant, though only with $90 \%$ certainty $(p=0.084)$.

The woody species cover (sum of the cover of all the woody species found) tends to increase over time and exceeds $100 \%$ (due to strata superposition) in the HS and HSO plots from the fifth year after burning (J.98) and in all the plots after 10 years (Fig. 4). In spite of the greater mean cover of woody species in the plots sown with Cytisus, no statistically significant differences can be detected or differences be observed between cover 10 years after burning and the initial situation. As regards herb cover (sum of the cover of all the herb species found, sown and unsown), no differences can be observed between the different 

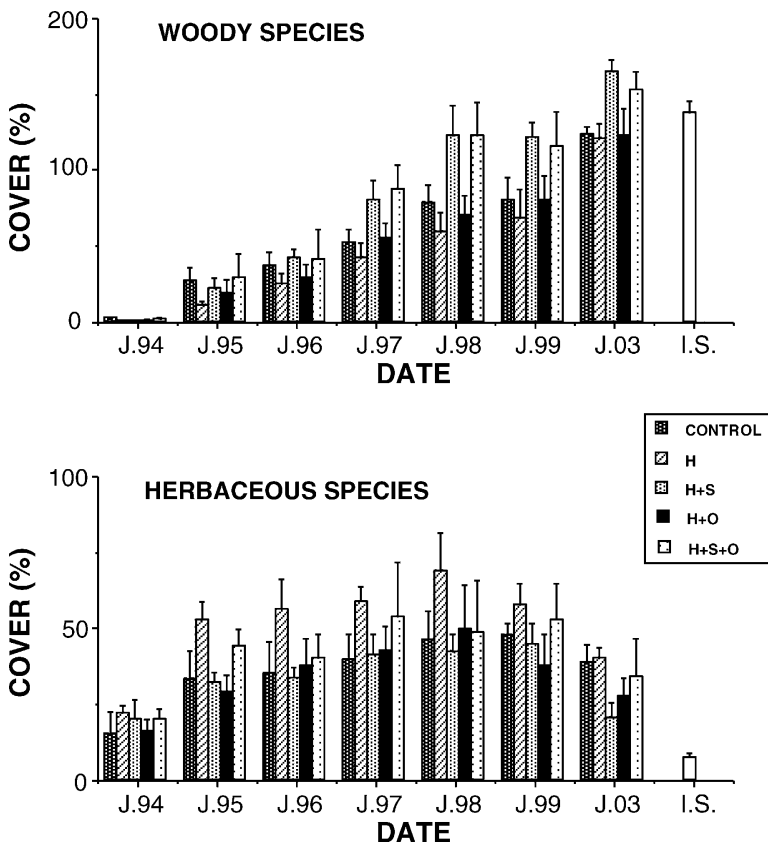

Fig. 4. Mean and standard error of woody and herbaceous cover values in the plots during the study period.

treatments at any sampling period though they can be on comparing the last sampling with the initial situation when the herbs were much less abundant $(p=0.003)$. No differences are detected in total cover (sum of the last two) or between treatments or between values in the last sampling and the initial situation.

Diversity (estimated as richness of species per $\mathrm{m}^{2}$ ) presents no statistically significant differences in terms of treatment, or the number of woody species, or of herbs, or of the total, but differences are detected over time. The greatest woody richness occurs in most plots in the last sampling coinciding with the lowest herb richness (Fig. 5). In spite of this decrease in herbs, the number continues higher after 10 years than in the initial situation $(p=0.003)$, and also total richness $(p=0.001)$ as a consequence, but no differences can be detected in the case of woody species richness $(p=0.18)$.

The whole of the results obtained for each treatment was compared using a correspondence analysis. The percentage of variance explained by the first two axes is $45 \%$. The separation of the
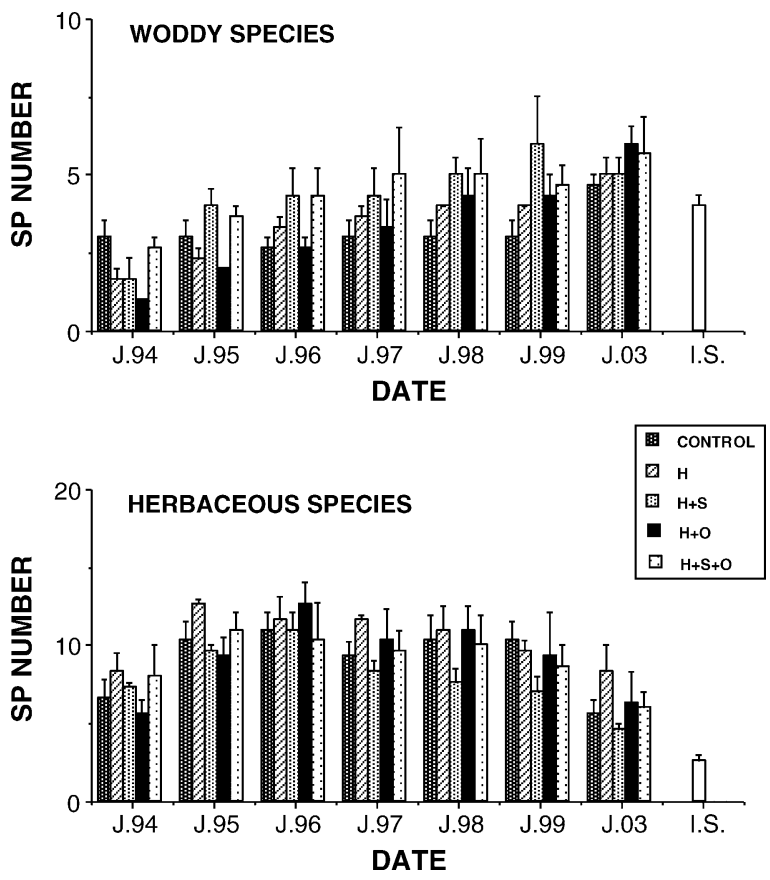

Fig. 5. Mean and standard error of woody and herbaceous richness values (species number $/ \mathrm{m}^{2}$ ) in the plots during the study period.

samplings carried out one year after burning (and three months after sowing) can be observed in association with unsown herb species, like Luzula forsteri, Holcus mollis and Senecio sylvaticum, which are situated towards the negative end of both axes (Fig. 6). The sampling carried out before burning, which is characterised by greater $C$. vulgaris cover, is at the positive end of axis II. In accordance with this, temporal ordination of the samplings corresponding to each treatment is observed depending on this second axis. The plots sown with Cytisus are situated at the positive end of axis I, with plots HS and HSO separated by the presence of $Q$. pyrenaica in the latter. The increase in Cytisus cover in these plots determines an increasingly greater separation in comparison with the initial situation, whilst the temporal tendency for the others (Control, $\mathrm{H}$ and $\mathrm{HO}$ ) is to become more similar. On comparing samplings on the same date between control and sown plots, the latter have more negative values for axis II associated with greater F. rubra, A. capillaris and $L$. corniculatus cover; these differences tend to diminish in the final samplings. 

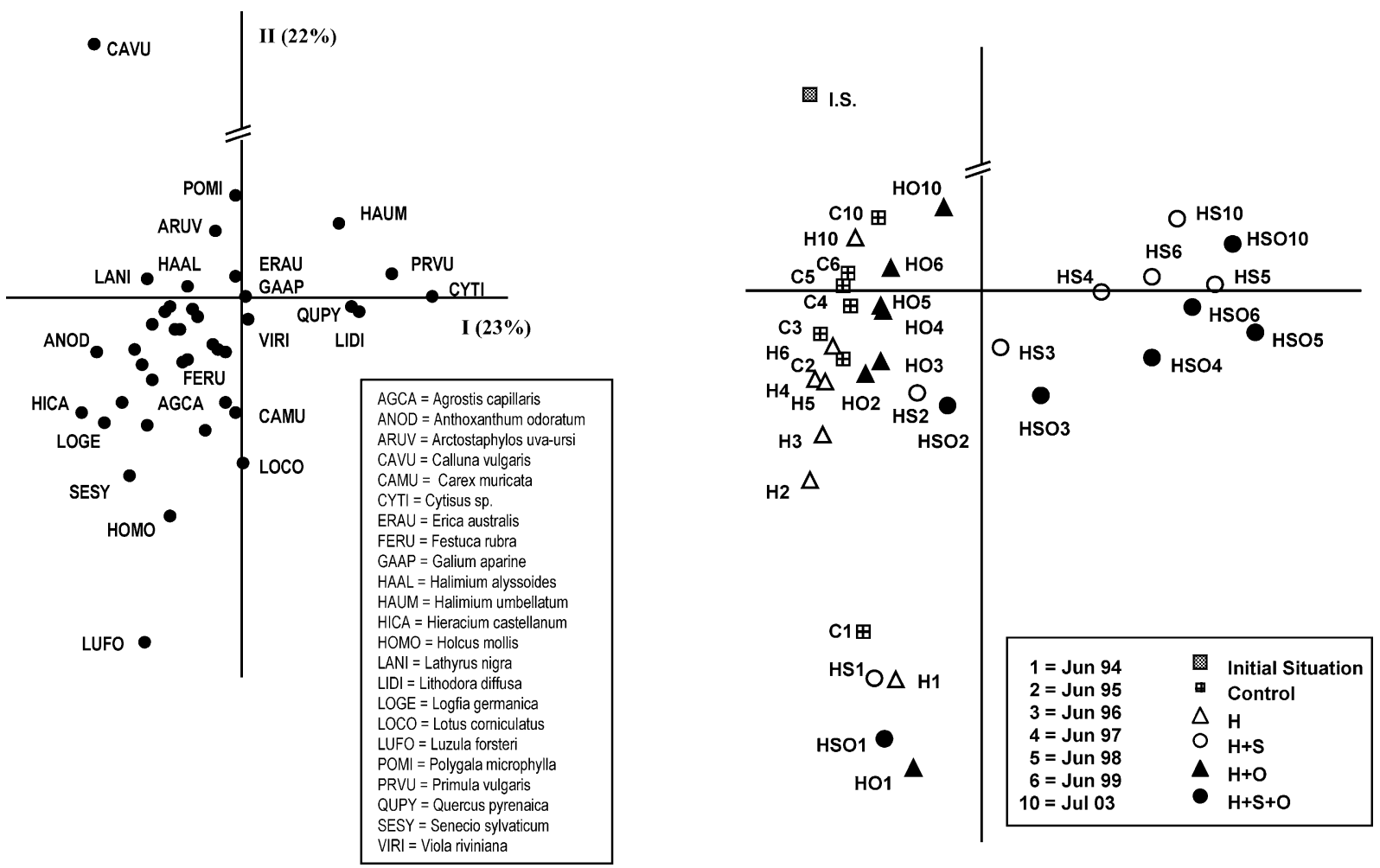

Fig. 6. Situation of species and samplings in the plane defined by the first two axes of correspondence analysis.

\section{Discussion}

Although mean cover of the herbaceous species sown is almost always greater in the sown plots than the controls, the differences are statistically significant in only a few cases. Moreover, the aim of sowing herbs is to increase cover in the short term and no significant differences were detected in the studied plots between the sown ones and the controls, or in herb cover or total cover. This differs from the results obtained in a heathland burned by a wildfire in which the same herbaceous species were sown and higher cover was observed during the first year (Fernández-Abascal et al., 2003). In that case sowing was in autumn, one month after the fire, instead of eight months after it in spring. This could partly explain the disparity in the results, in addition to the favourable meteorological conditions, whilst here the months following sowing (April and May 1994) were very cold and dry. Other authors have recorded an increase in initial though short-lasting cover on sowing herbs (Vallejo and Alloza, 1998). On the other hand, in this study it cannot be determined to what extent the presence of F. rubra, A. capillaris and L. corniculatus is due to sowing or their presence in the soil seed bank (Valbuena et al., 2000), as they were present in the area before the experimental fire.

It is not clear why $C$. vulgaris takes so long to reappear in the area. Although the seeds sown were not viable, it was present in the soil seed bank and, moreover, had a higher germination rate after the experimental fire (Valbuena et al., 2000). In a nearby heathland with similar characteristics, in which the response to three types of disturbance (burning, cutting and ploughing) are compared, C. vulgaris also does not appear in the first few years, although it regenerates well later, always from seeds (Calvo et al, 2002). In contrast, E. australis recovers by vegetative resprout and has cover similar to the initial situation five years after burning (June 1998). Neither species seems to be influenced by the different sowing treatments as no differences were observed in their cover values in any case. Cytisus spp., which was not found in the seed bank in the area (Valbuena et al., 2000), grew more 
slowly and had lower cover than E. australis in the first few years as the latter is a resprouter and starts from a well-developed root system. So, it only has to regenerate aboveground biomass. However, its cover is already equal to that of the resprouter three years after sowing and four after burning (June 1997) and even exceeds it considerably in the following years. The development of Cytisus spp. does not seem to slow down cover by E. australis, whose mean value increases in the last sampling. However, the results recorded by Marcos et al. (2004) indicate certain interference between E. australis and Cytisus spp., since a negative correlation is observed between the cover of both species eight years after burning when a more detailed analysis per square meter is carried out. Cytisus spp. have also been described as pioneer and generally shade intolerant (Polunin, 1976; Watt et al., 2003), although Tutin et al. (1964-1980) include woods as well as edges and heaths as habitats of $C$. scoparius and $C$. striatus. In the study area, the high cover of herbaceous and woody species does not impede colonisation by Cytisus, which tends to spread to the unsown plots, though slowly.

Much has been said about the advantages and disadvantages of sowing seeds or using seedlings (one or more years old) to revegetate with tree species (Vallejo et al., 2000; Espelta et al., 2003). In this case, an intermediate option was preferred in order to avoid acorn depredation (although the plots were enclosed, it is impossible to stop them being eaten by birds, rodents, etc.) and, at the same time, the early seedling transplant (two months) would avoid unwanted habits in root growth. The survival rate observed in the oak seedlings is considerably higher than that recorded on sowing $Q$. pyrenaica acorns in burned areas of NW Spain, with only $2.2 \%$ seedling emergence (Reyes et al., 2000) and 32\% survival of emerged seedlings (Reyes and Casal, 2002). It is also the same as or higher than that recorded on planting one-year-old seedlings of $Q$. ilex in semiarid and subhumid Mediterranean climates (Vallejo and Alloza, 1998; Vallejo et al., 2003). Insignificant growth is observed in that study after eight years and is attributed to the poor soil and the drought (Vallejo et al., 2003). Although the soil of the studied heathland, the result of secondary succession in old fields, is probably more degraded than the forest soil of the oak woods in the area; the climatological conditions are suitable for the development of $Q$. pyrenaica as there is an oak wood pasture ('dehesa') with large specimens very close to the experimental plots. The small height growth of the $Q$. pyrenaica seedlings contrasts with their growth dynamic when they are from vegetative resprout, their normal method of recovery after a fire, when they reach $2 \mathrm{~m}$ in height after two years (Luis-Calabuig et al., 2000). However, the great resprout capacity is also shown in this study as the root system, even in two-month-old seedlings, is capable of surviving and recovering the aboveground biomass when this is not able to survive unfavourable conditions. The limited growth of the oak seedlings could be due to competition with the shrub resprouting species, which would have an advantage in using resources. On the other hand, the shrub species could protect the oaks from excess desiccation, which would explain the fact that mortality does not occur in the aboveground biomass in the last years when shrub cover is abundant. Cytisus spp. had no influence on the survival rate as the mortality of the $Q$. pyrenaica seedlings occurred in the first few months after they were planted when cover of this legume was insignificant. However, it does seem to have a certain positive effect on growth but, given the small size of the oaks, it is too soon to state whether it will have any repercussions on future growth dynamic.

The cover by Cytisus determines higher mean values for woody species cover, although no significant differences can be detected. However, this effect, which is very evident five years after burning (J.98), tends to diminish over time. In any case, the high-woody species cover, which considerably exceeds $100 \%$ even in the initial situation, has to be highlighted. This is attributed to strata superposition with creeping species, such as Arctostaphylos uvaursi, others of larger size, such as E. australis or Cytisus spp., and other intermediate ones, such as Halimium alyssoides and $H$. umbellatum. However, all these shrubs tend to branch from the base, so appear to be profusely intermixed with considerable canopy overlap. Competition among them would therefore seem likely at least for space (Marcos et al., 2004). Another aspect worth mentioning is that, in spite of the great abundance of woody species, herb cover as well as diversity (number of species) is significantly higher than in the initial situation, even 10 years after burning. The increase in herbs in the first stages of 
post-fire recovery has been mentioned by various authors (Naveh, 1974; Trabaud and Lepart, 1980; Bond and van Wilgen, 1996; Luis-Calabuig et al., 2000; Reyes et al., 2000) but is normally restricted to the first two or three years after the fire, decreasing to initial values as the shrub species recover their levels of cover. The results obtained in this study cannot be attributed only to sowing since they are also observed in the control plots.

Although significant differences cannot be detected regarding treatment in the plant cover or species diversity, it is clear that the type of revegetation has determined changes in the plots. This is shown globally in the correspondence analysis in which the plots sown with Cytisus progressively separate from the rest over time. However, although this may be the most evident (in analysis as well as in the field due to the great cover reached by this shrub, which determines significant changes in the physiognomic aspect of the heathland), it does not prevent a certain separation between the HS and HSO plots also being detected due to the presence of $Q$. pyrenaica, and the same can be said of each type of plot, except in the first sampling in all of them (June 94), which is very similar. In the revegetation experiment using herbs in a heathland burned by a wildfire (Fernandez-Abascal et al., 2003), a temporal tendency to return to the initial plant composition is observed. This can also be observed in the control plots and in those sown only with herbs $(\mathrm{H})$ or herbs and oak (HO). However, in the latter oak tends to significantly increase its cover and height in the last sampling, and although these values are still very low, important changes could occur if the growth tendency is maintained.

Therefore, it can be concluded from the results obtained so far that although the revegetation treatments carried out were not effective in re-covering the soil in the short term due to the lack of success of the sown herbs in comparison with natural regeneration, they could have important implications in the successional dynamic of the community in the medium or long term.

\section{Acknowledgement}

This paper is part of a research project supported by the C.I.C.Y.T. (NAT91-1031-C03-01).

\section{References}

Alberdi, L., Cavero, R.Y., 2001. Desarrollo de técnicas que aceleren el proceso de recuperación de la flora vascular tras un incendio en un carrascal de Navarra. Actas del III Congreso Forestal Español. Granada, 521-526.

Bond, W.J., van Wilgen, B.W., 1996. Fire and Plants. Chapman and Hall, New York.

Calvo, L., Tárrega, R., Luis, L., 2002. The dynamics of Mediterranean shrubs species over 12 years following perturbations. Plant Ecol. 160, 25-42.

Cochran, W.G., 1941. The distribution of the largest of a set estimated variances as a fraction of their total. Ann. Eugenics 11, 47-61.

Conard, S.G., Beyers, J.L., Wohlgemuth, P.M., 1995. Impacts of post-fire grass seeding on chaparral systems-what we know and where do we go from here. In: Keeley, J.E., Scott, T. (Eds.), Brushfires in California Wildlands: Ecology and Resource Management. Association of Wildland Fire, Fairfield, Washington, pp. 149-161.

David, H.A., Hartley, M.O., Pearson, E.S., 1954. The distribution of the ratio, in a single normal sample of range to standard deviation. Biometrika 41, 482-493.

Diaz-Fierros, F., Benito, E., Vega, J.A., Castelao, A., Soto, B., Perez-Moreira, R., Taboada, T., 1990. Solute loss and soil erosion in burnt soil from Galicia (NW Spain). In: Goldammer, J.G., Jenkins, M.J. (Eds.), Fire in Ecosystem Dynamics. SPB Academic Publishing, The Hague, pp. 103-116.

Espelta, J.M., Retana, J., Habrouk, A., 2003. An economic and ecological multi-criteria evaluation of reforestation methods to recover burned Pinus nigra forest in NE Spain. Forest Ecol. Manage. 180, 185-198.

Fernández-Abascal, I., Luis, E., Tárrega, R., Valbuena, L., 1998. Five years of recovery after experimental fire in a heathland. Effects of sowing native species. In: Viegas, E.X. (Ed.), Proceedings of the 3rd International Conference on Forest Fire Research. Coimbra, pp. 1889-1899.

Fernández-Abascal, I., Luis, E., Tárrega, R., Marcos, E., 2002. Trends in post-fire biomass recovery in an Erica australis heathland. In: Trabaud, L., Prodon, P. (Eds.), Fire and Biological Processes. Bachuys Publishers, Leiden, pp. 33-42.

Fernández-Abascal, I., Tárrega, R., Luis, E., Marcos, E., 2003. Effects of sowing native herbaceous species on the post-fire recovery in a heathland. Acta Oecologica 24, 131-138.

Fernández-Santos, B., Gómez-Gutierrez, J.M., 1994. Changes in Cytisus balansae populations after fire. J. Veg. Sci. 5, 463-472.

Fernández-Santos, B., Gómez-Gutierrez, J.M., Moreno-Marcos, G., 1999. Effects of disturbance caused by traditional Spanish rural land use on the regeneration of Cytisus multiflorus. Appl. Veg. Sci. 2, 239-250.

Luis-Calabuig, E., Tárrega, R., Calvo, L., Marcos, E., Valbuena, L., 2000. History of landscape changes in northwest Spain according to land use and management. In: Trabaud, L. (Ed.), Life and Environment in the Mediterranean. Wit press, Southampton, pp. 43-86.

Marcos, E., Tárrega, R., Luis, E., 2000. Comparative analysis of runoff and sediment yield with a rainfall simulator 
after experimental fire. Arid Soil Res. Rehabilitation 14, 293307.

Marcos, E., Tárrega, R., Luis, E., 2004. Interactions between Mediterranean shrub species eight years after experimental fire. Plant Ecol. 170, 235-241.

Miles, S.R., Haskins, D.M., Ranken, D.W., 1989. Emergency burn rehabilitation: cost, risk and effectiveness. Proc. of the Symposium on Fire and Watershed Management. USDA. Gen. Tech. Re PSW-109. 97-102.

Moreno, J.M., Vazquez, A., Velez, R., 1998. Recent history of forest fires in Spain. In: Moreno, J.M. (Ed.), Large Forest Fires. Backhuys Publishers, Leiden, pp. 159-185.

Naveh, Z., 1974. Effects of fire in the Mediterranean region. In: Kozlowski, T.T., Ahlgren, C.E. (Eds.), Fire and Ecosystems. Academic Press, New York, pp. 401-434.

Pausas, J.G., Vallejo, R., 1999. The role of fire in European Mediterranean ecosystems. In: Chuvieco, E. (Ed.), Remote Sensing of Large Forest Fires in the European Mediterranean Basin. Springer, pp. 3-16.

Pérez, B., Cruz, A., Fernández-González, F., Moreno, J.M., 2003. Effects of the recent land-use history on the post-fire vegetation of uplands in Central Spain. Forest Ecol. Manage. 182, 273-283.

Polunin, O., 1976. Trees and Bushes of Europe. Oxford University Press, London.

Reyes, O., Basanta, M., Casal, M., Diaz-Vizcaino, E., 2000. Functioning and dynamics of woody plant ecosystems in Galicia (NW Spain). In: Trabaud, L. (Ed.), Life and Environment in the Mediterranean. Wit press, Southampton, pp. 1-39.

Reyes, O., Casal, M., 2002. Experimental field emergence and early survival of six tree species in relation to forest fires. In: Trabaud, L., Prodon, P. (Eds.), Fire and Biological Processes. Bachuys Publishers, Leiden, pp. 277-290.

Ruby, E.C., 1989. Rationale for seeding grass on the Stanislaus Complex burn. Proc. of the Symposium on Fire and Watershed Management. USDA. Gen. Tech. Re PSW-109. 125-130.

Scheffe, H., 1959. The Analysis of Variance. John Wiley and Sons, Inc., New York.
Tárrega, R., Calvo, L., Trabaud, L., 1992. Effects of high temperatures on seed germination of two woody Leguminosae. Vegetatio 102, 139-147.

Ter Braak, C.J.F., 1991. CANOCO (version 3.12). A FORTRAN program for canonical community ordination by/partial/ detrended/canonical/correspondence analysis, principal components analysis and redundancy analysis. TNO, Wageningen.

Trabaud, L., 1987. The Role of Fire in Ecological Systems. SPB Academic Publishing, The Hague.

Trabaud, L., Lepart, J., 1980. Diversity and stability in garrigue ecosystems after fire. Vegetatio 43, 49-57.

Tutin, T.G., Heywood, U.H., Burges, N.A., Moore, D.M., Walters, S.M., Webb, D.A., 1964-1980. Flora Europaea. Cambridge University Press, Cambridge.

Vallejo, R., Alloza, J.A., 1998. The restoration of burned lands: the case of Eastern Spain. In: Moreno, J.M. (Ed.), Large Forest Fires. Backhuys Publishers, Leiden, The Netherlands, pp. 91108.

Vallejo, R., Bautista, S., Cortina, J., 2000. Restoration for soil protection after disturbances. In: Trabaud, L. (Ed.), Life and Environment in the Mediterranean. WIT Press, Boston, pp. 301343.

Vallejo, R., Cortina, J., Vilagrosa, A., Seva, J.P., Alloza, J.A., 2003. Problemas y perspectivas de la utilización de leñosas autóctonas en la restauración forestal. In: Rey Benayas, J.M., Espigares Pinilla, T., Nicolau Ibarra, J.M., (Eds.), Restauración de Ecosistemas Mediterráneos. Universidad de Alcalá, Servicio de Publicaciones, Alcalá de Henares, 1142.

Valbuena, L., Tárrega, R., Luis, E., 2000. Seed bank of Erica australis and Calluna vulgaris in a heathland subjected to experimental fire. J. Veg. Sci. 11, 161-166.

Watt, M.S., Clinton, P.W., Whitehead, D., Richardson, B., Mason, E.G., Leckie, A.C., 2003. Aboveground biomass accumulation and nitrogen fixation of broom (Cytisus scoparius L.) growing with juvenile Pinus radiata on a dryland site. Forest Ecol. Manage. 184, 93-103. 